\title{
Performance of corrosion protection of carbon steel with cerium modified phosphate-permanganate coatings and a layer of silane doped with cerium
}

\section{O. Girčiené,}

L. Gudavičiūtè,

A. Martušienè,

V. Jasulaitienè,

A. Selskienè,

\section{R. Ramanauskas}

Center for Physical Sciences and Technology,

3 Sauletekio Avenue,

10257 Vilnius, Lithuania
This work was aimed to evaluate the effect of bis-[triethoxysilylpropyl] tetrasulfide (BTESPT) doped with cerium nitrate, as a corrosion inhibitor, on improved corrosion resistance of samples of carbon steel with a phosphate-permanganate layer in a $0.5 \mathrm{M} \mathrm{NaCl}$ solution. The main goal of the present work was to compare self-healing capacities of cerium conversion coatings and cerium as an additive inhibitor to silane. The composition and structure of the investigated samples were characterized by scanning electron microscope (SEM) and X-ray photoelectron spectroscopy (XPS) techniques, while the corrosion behaviour was investigated applying voltametric and electrochemical impedance spectroscopy (EIS) measurements. The results of EIS measurements performed during $24 \mathrm{~h}$ immersion of the investigated samples into the $0.5 \mathrm{M} \mathrm{NaCl}$ solution revealed that the layer of silane doped with Ce was more protective than that of the non-modified one. It has been determined that the presence of cerium nitrate in the silane coating can lead to high values of low frequency impedance due to the healing of the defect.

Keywords: corrosion protection, self-healing, phosphate-permanganate, cerium, silane

\section{INTRODUCTION}

The traditional surface passivation treatment for steel is the conversion coating which produces, by means of dissolution of the base metal through the reaction with the passivating solution and precipitation of insoluble compounds, a layer of corrosion products capable of resisting further chemical attack. The chromate based coatings have been widely applied as a pretreatment for different metal/alloys in order to protect substrates from corrosion. These coatings have unrivalled self-healing abilities, which are believed to arise from the migration of a soluble $\mathrm{Cr}(\mathrm{VI})$ compound in the coating to a scratch or defect, where they are reduced to

\footnotetext{
${ }^{*}$ Corresponding author. Email: olga.girciene@ftmc.lt
}

form a new protection layer [1, 2]. However, due to its toxicity, a substitute for the environmentally unfriendly chromate metal-surface pre-treatment is required. The replacement of chromate conversion layers by a new generation of conversion coatings called 'environmentally friendly' has been strongly stimulated in the last years and non-chromate coatings have been studied, such as permanganate [3, 4], phosphate-permanganate [5-9], rare earth and other based materials [10-20]. The phosphate-permanganate coatings are comparable to chromate conversion coatings for the protection of magnesium alloys, but unlike chromate conversion coatings, phosphate-permanganate coatings do not show any ability to regenerate [7].

Like chromate, rare earth metals can be deposited onto metal surfaces as conversion coatings. Rare 
earth metal ions, especially cerium and lanthanum salts, are known to inhibit corrosion processes on several substrates such as steel [10, 11], galvanized steel [12-14] and aluminium and its alloys [15, 16]. In a series of studies on the use of a cerium ion in protective coatings, Hinton and Wilson reported that the cerium ion, which acts as an inhibitor in the solution, was as effective as the chromium ion [19]. The action of the cerium ion resembled that of the chromium ion, and $\mathrm{CeO}_{2}$ acted as a barrier film. When a defect was generated, the cerium ion in the film repaired it, due to dissolution from the film and oxidation of the defect site [20].

A sol-gel coating can be applied to a metal substrate through various techniques, such as dip-coating and spin-coating, which are the two most commonly used coating methods. This coating is a passive organic coating, since it acts essentially as a physical barrier that hinders the penetration of aggressive species towards the metallic substrate. However, these coatings cannot offer an adequate long-term protection effect due to the presence of micro-pores, defects and areas with low cross-link density. In order to provide long-term protective effects, a corrosion inhibitor should be incorporated into these sol-gel films [21-26]. Thus, the doped sol-gel film acts as a reservoir of corrosion inhibitors that, in an aggressive medium, diffuse within the coating and reduce corrosion activity. The modification of silane coatings through doping with cerium nitrate is a procedure that combines the good barrier properties of the silane coating with the corrosion inhibition properties of the cerium ions [21-26.

This work was aimed to evaluate the effect of bis-[triethoxysilylpropyl] tetrasulfide (BTESPT) doped with cerium nitrate, as a corrosion inhibitor, on improved corrosion resistance of carbon steel samples in a $0.5 \mathrm{M} \mathrm{NaCl}$ solution. The main goal of the present work was to compare self-healing capacities of cerium conversion coatings and cerium as an additive inhibitor to silane for active corrosion protection of carbon steel coated with a phosphate-permanganate layer. The composition and structure of the investigated samples were characterized by scanning electron microscopy and X-ray photoelectron spectroscopy techniques. The bis[triethoxysilylpropyl] tetrasulfide silane coatings were assessed for their corrosion behaviour using voltametric measurements and the electrochemical impedance spectroscopy (EIS) technique.

\section{EXPERIMENTAL}

\section{Materials and sample preparation}

Test specimens with an area of $4 \mathrm{~cm}^{2}$ were prepared from carbon steel of the composition (wt.\%): C $0.21 \%$, Mn $1.2 \%$, Si $0.6 \%, \mathrm{Cr} \leq 0.3 \%, \mathrm{Ni}<0.3 \%$, $\mathrm{Cu}<0.3 \%, \mathrm{P}<0.4 \%, \mathrm{~S}<0.045 \%$. The samples were previously polished with emery paper up to grade 600 , degreased with ethanol and rinsed with distilled water.

The phosphate-permanganate conversion coating $(\mathrm{MnO})$ was obtained by immersion of a carbon steel sample into a solution containing: $0.1 \mathrm{M}$ $\mathrm{KMnO}_{4}, 0.15 \mathrm{M} \mathrm{H}_{3} \mathrm{PO}_{4}, 0.003 \mathrm{M} \mathrm{H}_{2} \mathrm{C}_{2} \mathrm{O}_{4}, \mathrm{pH}=4-5$, $70^{\circ} \mathrm{C}, 0.5 \mathrm{~h}$.

The cerium conversion coatings $\mathrm{Ce} 1$ and $\mathrm{Ce} 2$ were formed by a simple immersion of the samples for $24 \mathrm{~h}$ at $25^{\circ} \mathrm{C}$ into solutions containing $0.05 \mathrm{M}$ $\mathrm{Ce}\left(\mathrm{NO}_{3}\right)_{3}$ and $0.05 \mathrm{M} \mathrm{Ce}\left(\mathrm{NO}_{3}\right)_{3}+0.025 \mathrm{M} \mathrm{Na}_{2} \mathrm{SO}_{4}$, respectively.

The solution for the silane coating B was prepared by dissolving $4 \%(\mathrm{v} / \mathrm{v})$ of bis-[triethoxysilylpropyl] tetrasulfide (BTESPT) in a mixture of ethanol $(90.5 \% \mathrm{v} / \mathrm{v})$ and deionized water $(5.5 \% \mathrm{v} / \mathrm{v})$. The solution for the sol-gel coating doped with cerium (BCe) was prepared by dissolving $4 \%(\mathrm{v} / \mathrm{v})$ of BTESPT in a mixture of ethanol $(90.5 \% \mathrm{v} / \mathrm{v})$ and an aqueous solution of $0.001 \mathrm{M} \mathrm{Ce}\left(\mathrm{NO}_{3}\right)_{3}$ $(5.5 \% \mathrm{v} / \mathrm{v})$. The solutions were stirred for one hour and stored for 3 days before being used for the pretreatment of the investigated samples. The samples were immersed into the solution B or BCe for $10 \mathrm{~s}$ and cured at $120^{\circ} \mathrm{C}$ for $40 \mathrm{~min}$ [27].

The investigated multilayer coatings systems consisted of a MnO layer, two types of cerium conversion coatings $\mathrm{Ce} 1, \mathrm{Ce} 2$ and, additionally, an outer layer of BTESPT or BTESPT doped with cerium.

\section{Morphology and composition}

The microstructure and elemental composition of specimens were studied by a scanning electron microscope (SEM). A Helios NanoLab 650 dual beam workstation (FEI) with an X-Max $20 \mathrm{~mm}^{2}$ energy dispersive detector (energy resolution of $127 \mathrm{eV}$ for $\mathrm{Mn} \mathrm{Ka}$, Oxford Instruments) was used for imaging and energy dispersive analysis. The deposited film thickness analysis was performed on the produced and vacuum Pt coated cross-sections of the samples by the focused ion beam (FIB) technique. 
The X-ray photoelectron spectroscopy (XPS) studies were performed by a spectrometer ESCALAB using X-radiation of $\mathrm{MgKa}(1253.6 \mathrm{eV}$, pass energy of $20 \mathrm{eV}$ ). To obtain depth profiles, the samples were etched in a preparation chamber by ionized argon at a vacuum of $5 \times 10^{-4} \mathrm{~Pa}$. An accelerating voltage of ca. $1.0 \mathrm{kV}$ and a beam current of $20 \mu \mathrm{A} \mathrm{cm}^{-2}$ were used.

\section{Electrochemical measurements}

The corrosion behaviour of samples was investigated in an aerated stagnant $0.5 \mathrm{M} \mathrm{NaCl}$ solution. The electrolyte was prepared from analytical grade chemicals and deionized water. All electrochemical measurements were performed at ambient temperature with an Autolab PGSTAT302 potentiostat using a standard three-electrode system with a Pt counter electrode and a saturated $\mathrm{Ag} / \mathrm{AgCl}$ reference electrode. All potentials are reported versus the saturated $\mathrm{Ag} / \mathrm{AgCl}$ reference electrode. The corrosion current densities $\left(i_{\text {corr }}\right)$ were determined from voltammetric measurements by Tafel line extrapolation. A specimen was polarized with a potential scan rate of $0.5 \mathrm{mV} \mathrm{s}^{-1}$, from the cathodic to the anodic region. The polarization resistance $\left(R_{\mathrm{p}}\right)$ values were determined from linear polarization measurements, which were performed between $\pm 10 \mathrm{mV}$ around $E_{\text {corr }}$ after immersion into the solution for $1 \mathrm{~h}$, with a scan rate of $0.1 \mathrm{mV} \mathrm{s}^{-1}$.

The measurements of electrochemical impedance spectra (EIS) were performed at the open circuit potential with the FRA2 module applying a signal of $10 \mathrm{mV}$ amplitude in the frequency range of $20 \mathrm{kHz}$ to $0.001 \mathrm{~Hz}$. The data obtained were fitted and analysed using the EQUIVCRT program of Boukamp [28].

Electrochemical experiments were performed at least in triplicate.

\section{RESULTS AND DISCUSSION}

\section{Morphology and composition}

A generic way to protect metals from corrosion is to apply protective films or coatings. The silane bis-[triethoxysilylpropyl] tetrasulfide films exhibit high hydrophobic performance and, therefore, good potentialities for corrosion protection of different metallic substrates $[22,23,25,26$. Other corrosion protection systems that have been pro- posed are based on the formation of chemical conversion layers using a modified permanganate solution [29]. The $\mathrm{MnO}$ coating was applied prior to silane layer deposition. However, this coating offers only passive corrosion protection, therefore $\mathrm{MnO}$ was chosen as the base for the active corrosion protection film [29]. Active corrosion protection of metals implies not only mechanical covering of the protected surface with a dense barrier coating, but also provides self-healing properties, which allow durable protection even after partial damage of the coating. These properties can be achieved by introduction of specific corrosion inhibitors into the coating system. Cerium ions were specific corrosion inhibitors which were introduced into the coating system. In order to determine the most effective application of this inhibitor, the investigated $\mathrm{MnO}$ samples were coated with cerium conversion coatings $\mathrm{Ce} 1$ or $\mathrm{Ce} 2$ [29] and additionally with either a layer of silane MnOCe1/B, MnOCe2/B or $\mathrm{MnO}$ samples were coated with a layer of silane doped with cerium $\mathrm{MnO} / \mathrm{BCe}$. Recently, we have demonstrated [29] that the Mn $2 \mathrm{p}_{3 / 2}$ spectra of MnOCe1, MnOCe2 and $\mathrm{MnO}$ (without a silane layer) are composed of an asymmetric peak. The binding energy of this peak varied from $641.1 \mathrm{eV}$ to $643.25 \mathrm{eV}$ which suggests that $\mathrm{Mn}$ in the coatings are of variable valence $\left(\mathrm{Mn}_{3} \mathrm{O}_{4}, \mathrm{MnO}_{2}, \mathrm{Mn}_{2} \mathrm{O}_{3}, \mathrm{MnO}_{2}\right)$ [29].

The SEM images of the microstructure and cross-section of the $\mathrm{MnO} / \mathrm{BCe}$ sample are presented in Fig. 1. The thickness of the deposited $\mathrm{MnO}$ layer is $\sim 280 \mathrm{~nm}$ (Fig. 1). The phosphate-permanganate coating is compact and possesses a good adherence to the base metal. The formed silane coating is free of visible defects and cracks. The value of the average thickness of the silane film was from $\sim 100 \mathrm{~nm}$ to $\sim 390 \mathrm{~nm}$ (Fig. 1).

The Ce 3d spectra for MnOCe1 and MnOCe2 samples without silane layers were identical and both samples possessed a Ce $3 \mathrm{~d}_{3 / 2}$ peak at $916.3 \mathrm{eV}$ [29] characteristic of $\mathrm{Ce}^{4+}[12]$. The composition and the oxidation state of elements in the outer part of the Ce-doped silane coating ( $\mathrm{MnO} / \mathrm{BCe})$ was examined using XPS measurements. The spectra of O 1s, Fe $2 p_{3 / 2}$, Ce $3 d, P 2 p$, Si 2p, Mn 2p, N 1s and C 1s were recorded after surface sputtering with $\mathrm{Ar}^{+}$ions for an increasing period of time. In general, according to the XPS measurements, the top layer of the samples 


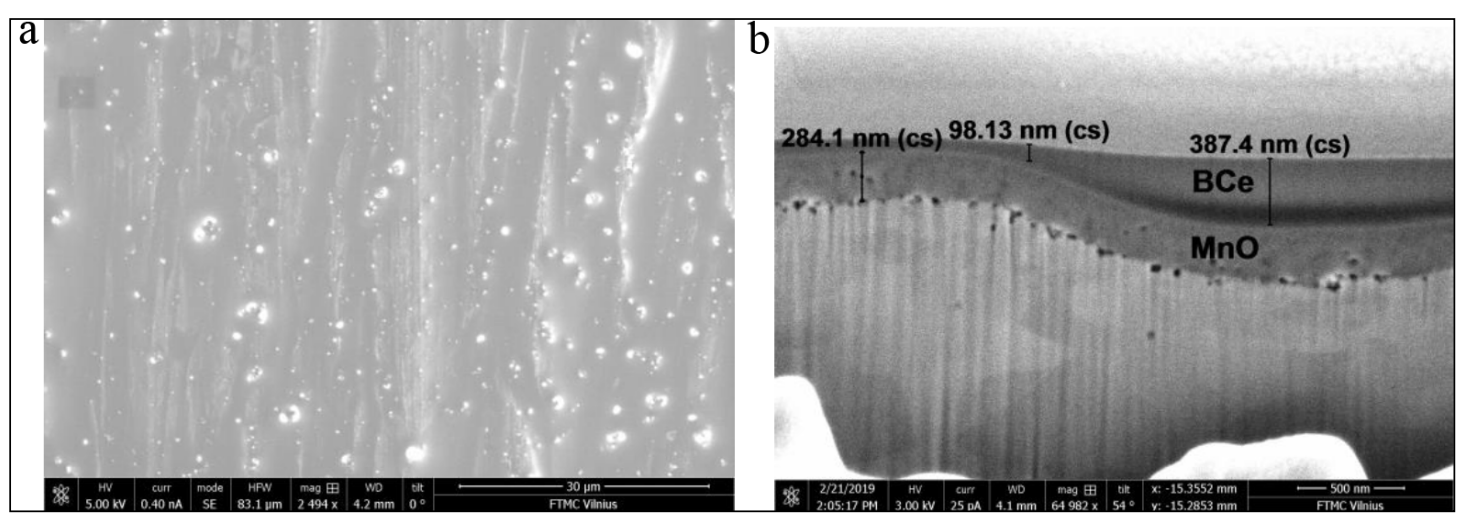

Fig. 1. SEM images of the microstructure (a) and the cross-section (b) of the MnO/BCe sample

$(0-20 \mathrm{~nm})$ seems to be rich in $\mathrm{C}, \mathrm{O}, \mathrm{S}$ and $\mathrm{Si}$. The spectra of $\mathrm{O} 1 \mathrm{~s}$ exhibited peaks at $533.53-534.01 \mathrm{eV}$, which may be assigned to $\mathrm{SiO}_{2}$, and $\mathrm{Si} 2 \mathrm{p}$ spectra exhibited a peak at $103.32-104.19 \mathrm{eV}$ also indicating $\mathrm{SiO}_{2}$. The peaks for the Ce $3 \mathrm{~d}$ region in the binding energy range from $880 \mathrm{eV}$ to $920 \mathrm{eV}$ were not sharp (Fig. 2) and the calculated amount of Ce in the top layer of the coating varied from 0.27 to 0.35 at.\%.

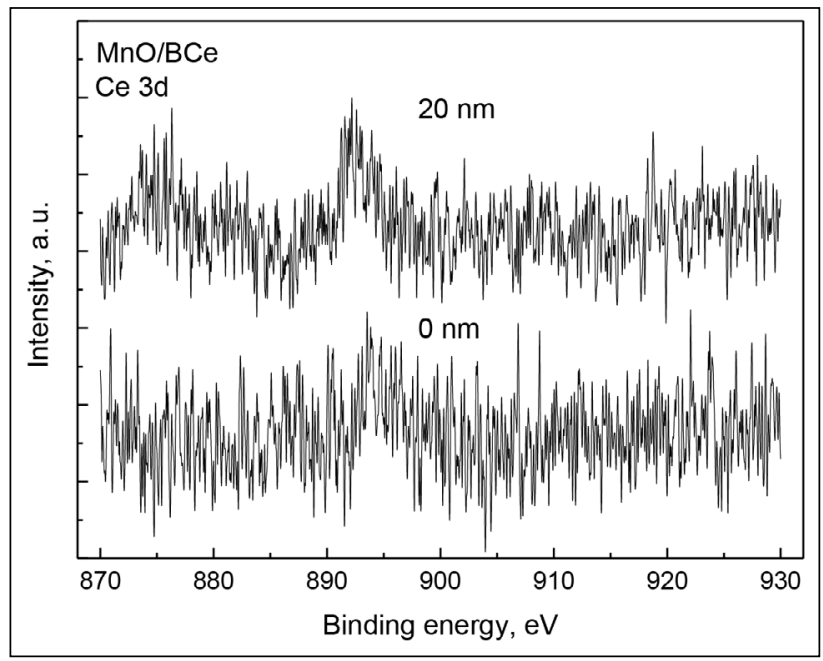

Fig. 2. XPS spectra for the Ce $3 \mathrm{~d}$ region obtained on the $\mathrm{MnO} / \mathrm{BCe}$ sample at different sputtering times

\section{Corrosion resistance}

\section{Potentiodynamic polarization measurements}

The corrosion behaviour of $\mathrm{MnO} / \mathrm{B}, \mathrm{MnO} / \mathrm{BCe}$, $\mathrm{MnOCe} 1 / \mathrm{B}$ and $\mathrm{MnOCe} 2 / \mathrm{B}$ samples was investigated by linear polarization measurements in a $0.5 \mathrm{M} \mathrm{NaCl}$ solution. The data obtained have shown that all samples exhibited more positive corrosion potential values $\left(E_{\text {corr. }}\right)$ as compared to those without a silane layer (Table 1). The values of $i$ corr were determined from the Tafel line (Fig. 3) extrapolation and the results obtained are listed in Table 1. As seen from the data, the samples with conversion coatings $\mathrm{Ce} 1, \mathrm{Ce} 2$ and treated with $\mathrm{B}$ exhibited the lowest values of $i_{\text {corr }} \sim 2.6 \cdot 10^{-7}-2.8 \cdot 10^{-7} \mathrm{~A} \mathrm{~cm}^{-2}$. The protection efficiency $P \%$ of the investigated samples was calculated by the equation [12, 13 ]

$$
P \%=\left(i_{\text {corr }}^{\circ}-i_{\text {corr }}\right) / i_{\text {corr }}^{\circ} \times 100,
$$

where $i_{\text {corr }}^{\circ}$ and $i_{\text {corr }}$ denote the corrosion current density of the electrode without [29] and with B or BCe coatings (Table 1), respectively. The results obtained imply that after $0.5 \mathrm{~h}$ exposure to

Table 1. The electrochemical parameters (corrosion potential $E_{\text {corr }}$ corrosion current density $i_{\text {corr }}$ polarization resistance $R_{\mathrm{p}}$ ) and protection efficiency $P \%$ of the investigated samples determined in $0.5 \mathrm{M} \mathrm{NaCl}$ solution

\begin{tabular}{|c|c|c|c|c|c|}
\hline \multirow{2}{*}{ Sample } & \multicolumn{5}{|c|}{ Electrochemical parameters } \\
\hline & $E_{\text {corr }}, \mathrm{V}$ (vs Ag/AgCl) & $i_{\text {corry }} A_{~ c m^{-2}}$ & P\% by Eq. (1) & $R_{\mathrm{p}}, \mathrm{k} \Omega \mathrm{cm}^{2}$ & P\% by Eq. (2) \\
\hline $\mathrm{MnO}[29]$ & -0.574 & $2.2 \times 10^{-6}$ & - & 2.91 & - \\
\hline $\mathrm{MnO} / \mathrm{B}$ & -0.454 & $7.1 \times 10^{-7}$ & 68 & 23.5 & 88 \\
\hline $\mathrm{MnO} / \mathrm{BCe}$ & -0.464 & $6.6 \times 10^{-7}$ & 70 & 26.4 & 89 \\
\hline MnOCe1/B & -0.448 & $2.8 \times 10^{-7}$ & 87 & 38.1 & 92 \\
\hline $\mathrm{MnOCe} 2 / \mathrm{B}$ & -0.499 & $2.6 \times 10^{-7}$ & 88 & 40.1 & 93 \\
\hline
\end{tabular}




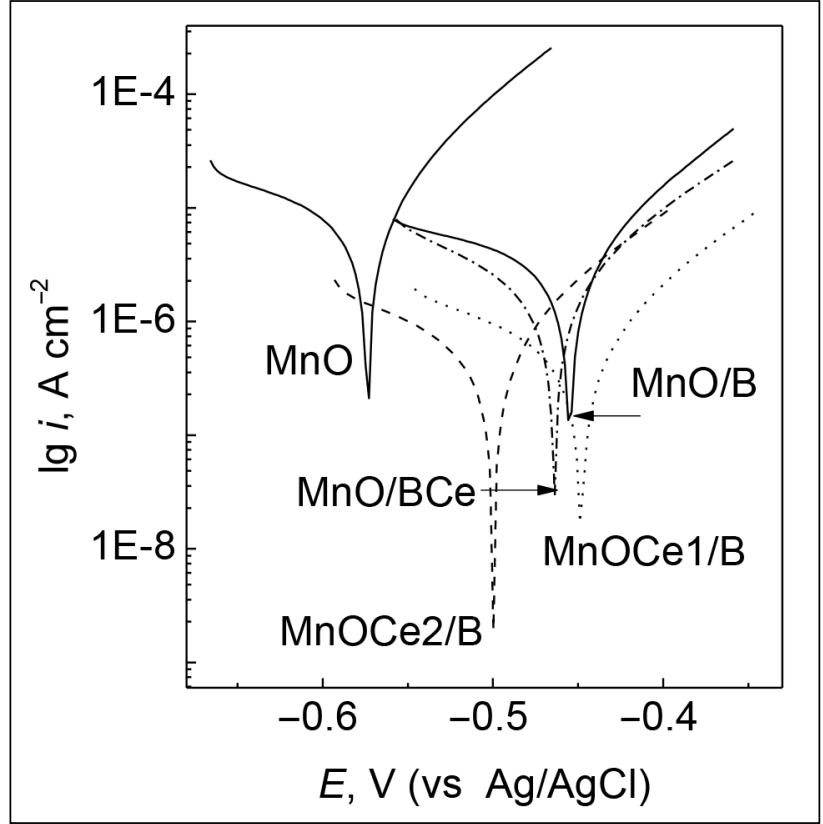

Fig. 3. Potentiodynamic polarization curves of the samples measured in $0.5 \mathrm{M} \mathrm{NaCl}$ solution at $25^{\circ} \mathrm{C}, 0.5 \mathrm{mVs}^{-1}$

the $0.5 \mathrm{M} \mathrm{NaCl}$ solution all investigated samples treated with a silane layer demonstrated better protective properties. The highest $P \%$ value was stated for the MnOCe2/B sample (Table 1).

The values of $R_{\mathrm{p}}$ of the investigated samples, which were determined from the linear polarization measurements $\pm 10 \mathrm{mV}$ around $E_{\text {corr }}$ are listed in Table 1. It is evident that all $\mathrm{MnO}$ (without/with Ce1, Ce2) samples additionally coated with B or BCe exhibited ninefold to fourteenfold higher $R_{\mathrm{p}}$ values, as compared with those of $\mathrm{MnO}$, respectively. The MnOCe1/B and MnOCe2/B samples exhibited the highest values of $R_{\mathrm{p}}$ (Table 1 ). The protection efficiency $P \%$ of the samples was calculated using the following equation [30]

$$
P \%=\left(R_{\mathrm{p}}-R_{\mathrm{pm}}\right) / R_{\mathrm{p}} \times 100
$$

where $R_{\mathrm{pm}}$ and $R_{\mathrm{p}}$ denote the polarization resistance of the MnO sample without and with B or BCe coatings (Table 1), respectively. The results obtained imply that the calculated values of $P \%$ increased from $88 \%(\mathrm{MnO} / \mathrm{B})$ up to $93 \%(\mathrm{MnOCe} / \mathrm{B})$. It can be stated, therefore, that the samples with the multilayer coatings exhibited better protective abilities with respect to those of the $\mathrm{MnO}$ samples. The silane layer acts mainly as a physical barrier covering the remaining active areas.

\section{EIS measurements}

A more detailed study of the coating degradation and the corrosion activity during its immersion into the corrosive media has been done using EIS. The EIS diagrams of the $\mathrm{MnO} / \mathrm{B}, \mathrm{MnO} /$ BCe, $\mathrm{MnOCe} 1 / \mathrm{B}$ and $\mathrm{MnOCe} 2 / \mathrm{B}$ samples after $0.5 \mathrm{~h}$ exposure to a $0.5 \mathrm{M} \mathrm{NaCl}$ solution are presented in Fig. 4. Two different electrical circuits models (Fig. 5a, b), which have been widely used for the analysis of impedance spectra of sol-gel coated metals [31, 32], were selected. The circuit shown in Fig. 5 a was used to fit the experimental data of the $\mathrm{MnO}$ samples coated with silane $\mathrm{B}$ without cerium, whose impedance magnitude $|Z|$ shows two well-defined time constants (Fig. 4a). The region between $10^{2}$ and $10^{5} \mathrm{~Hz}$ provides information on the sol-gel coating pore resistance $\left(R_{\text {coat }}\right)$ and capacitance $\left(C_{\text {coat }}\right)$. The low frequency region provides information on the corrosion process characterized by the charge transfer resistance $\left(R_{\mathrm{ct}}\right)$ and double layer capacitance $\left(C_{\mathrm{dl}}\right)$. In the case of $\mathrm{MnO} / \mathrm{BCe}, \mathrm{MnOCe} 1 / \mathrm{B}$ and $\mathrm{MnOCe} 2 / \mathrm{B}$ samples the third time constant corresponding to

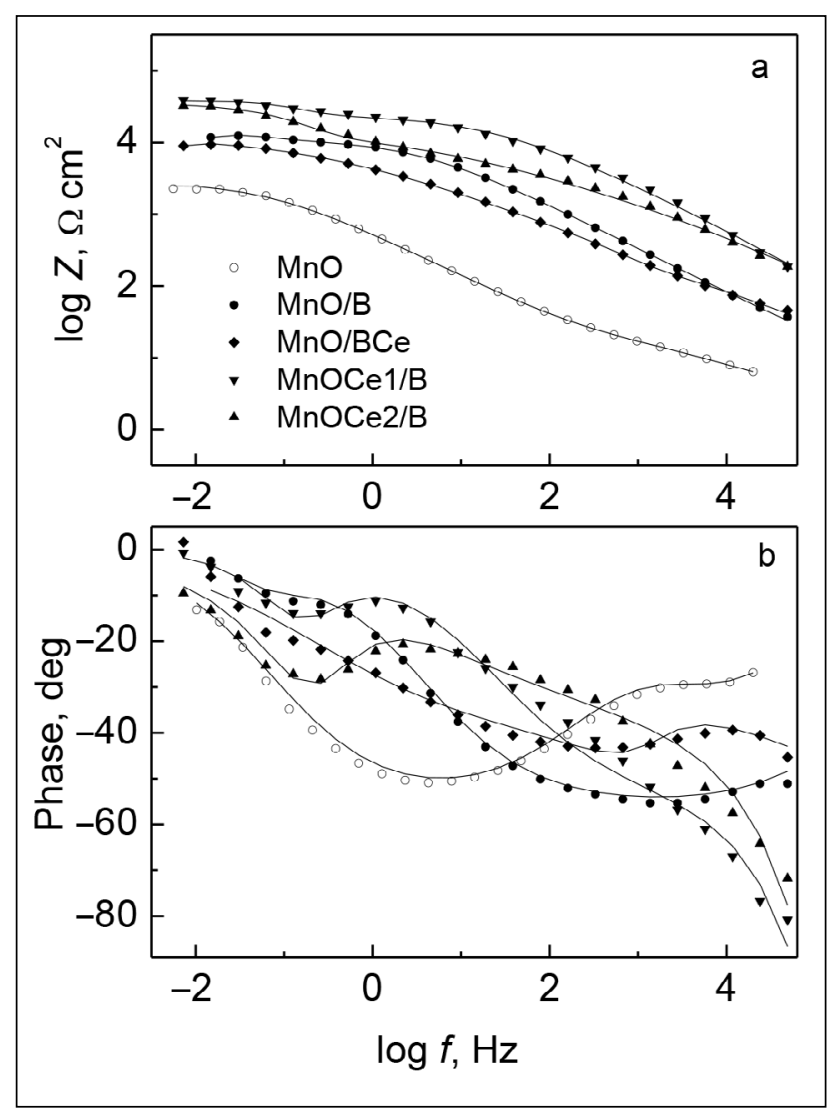

Fig. 4. Bode plots of EIS spectra after immersion of the investigated samples into $0.5 \mathrm{M} \mathrm{NaCl}$ solution for $0.5 \mathrm{~h}$ 


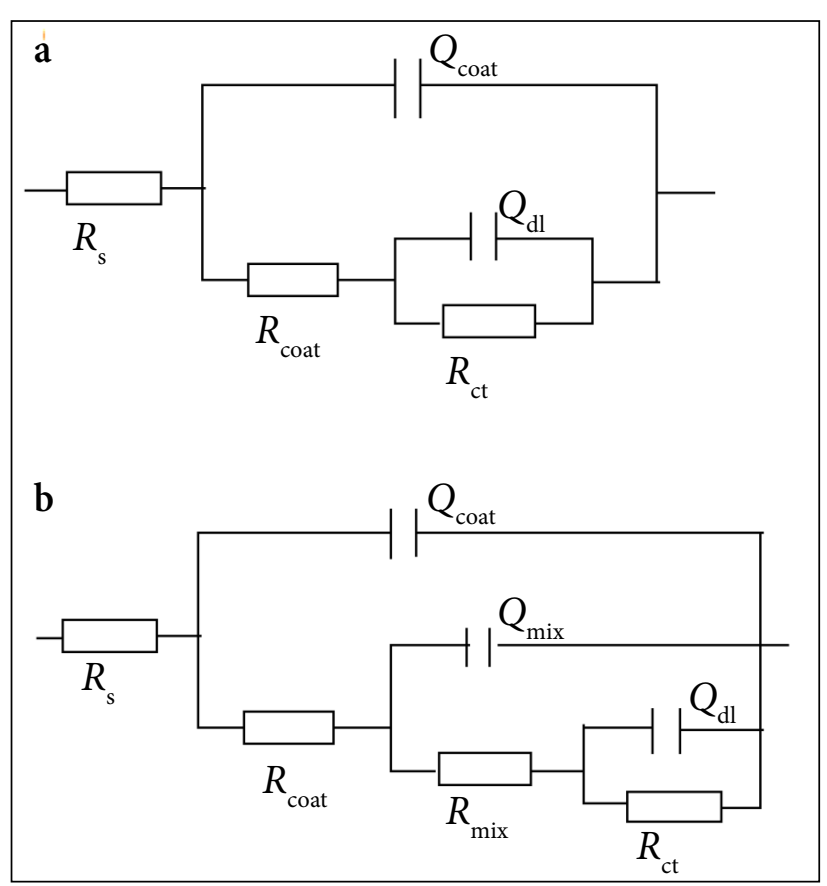

Fig. 5. Equivalent circuit models used for ElS data fitting

the contribution from the intermediate $\mathrm{MnO}$ and $\mathrm{Ce}$ oxide layers mainly appears at frequencies lower than $10^{2} \mathrm{~Hz}$. It will be observed that at low frequency the resistive part corresponding to $R_{\text {mix }}$ and $R_{\text {ct }}$ is not fully visible on EIS spectra and both time constants are overlapping. More detailed information on the mixed oxide layer resistance $\left(R_{\text {mix }}\right)$ and capacitance $\left(C_{\text {mix }}\right)$ can be extracted from the fitting of the EIS spectra using the equivalent circuit presented in Fig. $5 \mathrm{~b}$.

For fitting the data, all the capacitances in the equivalent circuits had to be replaced by constant phase elements (CPE) [33] to adapt for nonideal behaviour. $C P E$ instead of capacitors were actually used in the equivalent circuit models to account for a dispersive character of the time constants and inhomogeneous properties of the layers. CPE is marked as $Q$ in the circuit description code (CDC) and it is defined by the admittance $Y$ and the power index number $n$ : $Y=Y_{0}(j w)^{\mathrm{n}}$. The term $n$ shows how far the interface is from an ideal capacitor.

Applying equivalent circuits to fit the impedance spectra a set of fitting parameters was obtained (Table 2). In order to study the corrosion behaviour of the investigated samples impedance spectra were recorded for various immersion times. The graphics presented in Fig. 6 show the average values of $R_{\text {coat }}, R_{\text {mix }}$ and $R_{\text {ct }}$ which were obtained by fitting the impedance spectra
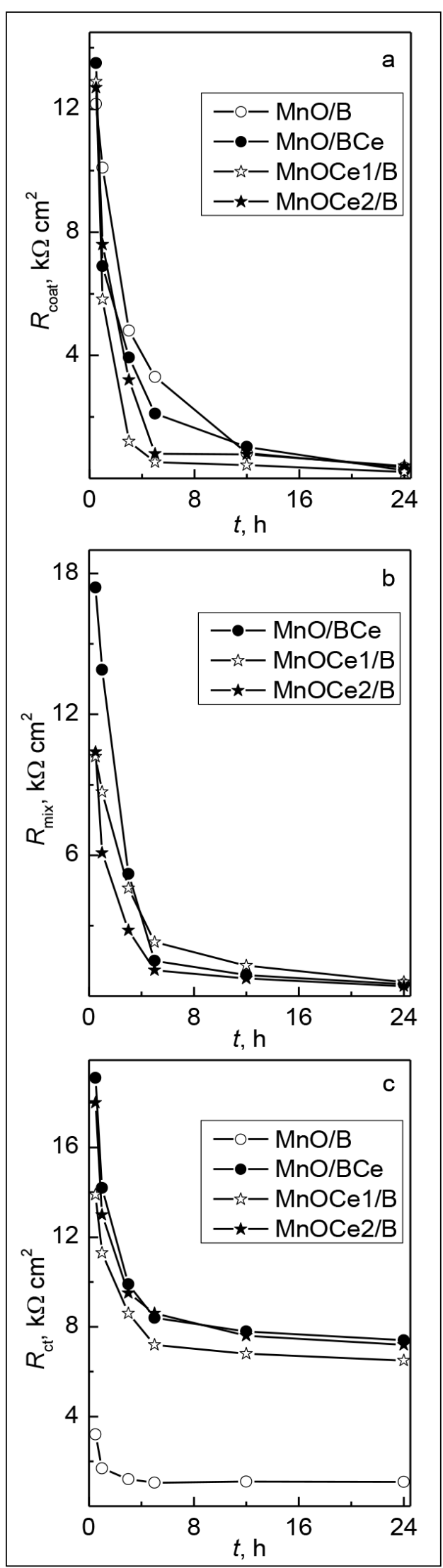

Fig. 6. Evolution of (a) the silane coating pore resistance $\left(R_{\text {coat }}\right)$, (b) the mixed oxide layer resistance $\left(R_{\text {mix }}\right),(\mathrm{c})$ the charge transfer resistance $\left(R_{\mathrm{ct}}\right)$ during immersion in $0.5 \mathrm{M} \mathrm{NaCl}$ solution 
of samples and their replicas. Evolution of the silane coating resistance $R_{\text {coat }}$ during immersion in the $0.5 \mathrm{M} \mathrm{NaCl}$ solution for $24 \mathrm{~h}$ is presented in Fig. 6a. At the beginning of measurements $R_{\text {coat }}$ values for all the coating systems were equal to $\sim 11.3-13.5 \mathrm{k} \Omega \mathrm{cm}^{2}$. The sol-gel coating acts mainly as a physical barrier covering the remaining active areas. A fast drop in $R_{\text {coat }}$ occurs during the first ten hours followed by a monotonous decrease during the whole immersion time. Whereas the coating capacitance $Q_{\text {coat }}$ rapidly grows, the $n$ value is $>0.5$ (Fig. 7a). The increase in $Q_{\text {coat }}$ may be attributed to hydrolytic degradation of the silane coating. The BTESPT coating does not provide a high barrier effect. The evo- lution of the intermediate mixed oxide layer resistance $R_{\text {mix }}$ for different samples is presented in Fig. $6 \mathrm{~b}$. The best performance was demonstrated for the $\mathrm{MnO} / \mathrm{BCe}$ system that shows the highest initial mixed oxide layer resistance of $\sim 17.4 \mathrm{k} \Omega$ $\mathrm{cm}^{2}$. During $24 \mathrm{~h}$ of immersion $R_{\text {mix }}$ monotonously decreases to $\sim 0.5 \mathrm{k} \Omega \mathrm{cm}^{2}$ for the $\mathrm{MnO} /$ $\mathrm{BCe}, \mathrm{MnOCe} 1 / \mathrm{B}$ and $\mathrm{MnOCe} 2 / \mathrm{B}$ samples, whereas the $Q_{\text {mix }}$ parameter is not stable and the evolution shows similar capacitance values for all samples (Fig. $7 \mathrm{~b}$ ). A low frequency part of the impedance spectra can be used to estimate the extent of corrosion activity. The evolution of the charge transfer resistance $R_{\text {ct }}$ values is presented in Fig. $6 c$ and that of the double layer
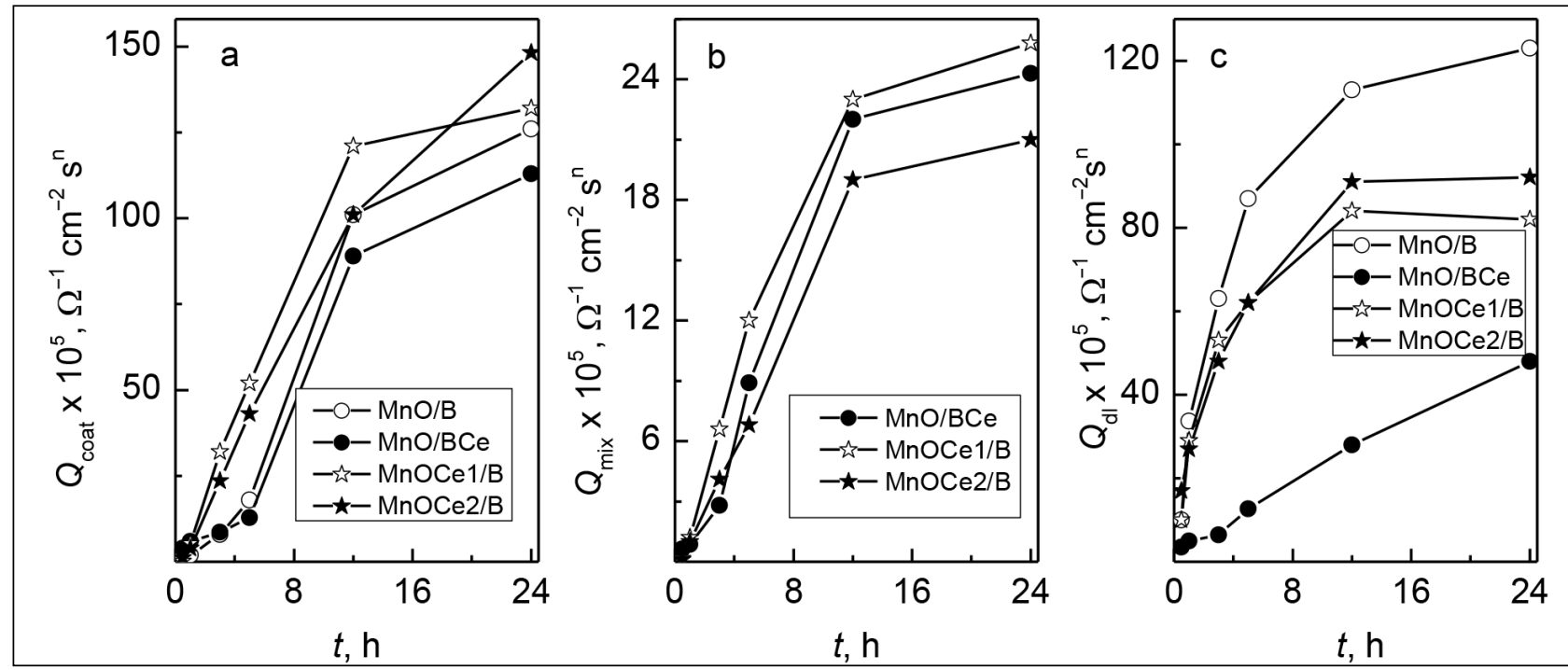

Fig. 7. Evolution of (a) the silane coating capacitance $\left(Q_{\text {coat }}\right),(\mathrm{b})$ the mixed oxide layer capacitance $\left(Q_{\text {mix }}\right),(\mathrm{c})$ the double layer capacitance $\left(Q_{\mathrm{ct}}\right)$ during immersion in $0.5 \mathrm{M} \mathrm{NaCl}$ solution

Table 2. ElS parameters obtained for $\mathrm{MnO} / \mathrm{B}, \mathrm{MnO} / \mathrm{BCe}, \mathrm{MnOCe} 1 / \mathrm{B}$ and $\mathrm{MnOC} 2 / \mathrm{B}$ using equivalent circuits shown in Fig. 4

\begin{tabular}{|c|c|c|c|c|c|c|c|c|c|}
\hline Sample & 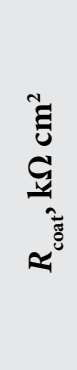 & 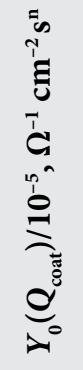 & 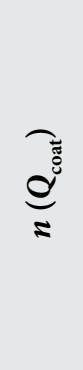 & 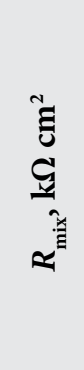 & 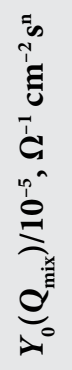 & $\stackrel{\overbrace{}^{0}}{a}$ & 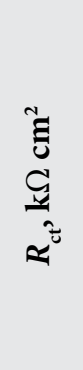 & 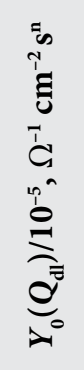 & 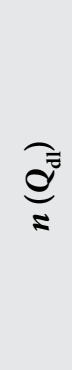 \\
\hline $\mathrm{MnO} / \mathrm{B}$ & 11.3 & 1.3 & 0.62 & - & - & - & 3.2 & 14.2 & 0.99 \\
\hline $\mathrm{MnO} / \mathrm{BCe}$ & 13.5 & 0.71 & 0.59 & 17.4 & 1.3 & 0.7 & 19.1 & 12.7 & 0.99 \\
\hline MnOCe1/B & 12.8 & 0.11 & 0.66 & 10.2 & 1.1 & 0.9 & 13.9 & 10.4 & 0.99 \\
\hline MnOCe2/B & 12.7 & 0.84 & 0.58 & 10.4 & 1.7 & 0.87 & 18.0 & 17.4 & 0.99 \\
\hline
\end{tabular}


capacitance $Q_{\mathrm{dl}}$ in Fig. \#c. With increasing immersion time, $R_{\mathrm{ct}}$ of all the investigated samples shows a tendency to decrease, whereas $Q_{\mathrm{dl}}$ has a tendency to increase. Such changes may indicate that $\mathrm{Cl}^{-}$ions reached the steel substrate. It is known that pores and defects that exist in a sol-gel coating can assist the ingress of electrolyte during immersion in a corrosive solution [31, 32]. Upon reaching the metal surface the aggressive species can initiate local corrosion processes which can develop into pitting if no counter measures are taken to suppress corrosion. After $24 \mathrm{~h} \mathrm{MnO} / \mathrm{B}$ reached the lowest value of $R_{\mathrm{ct}}=1.6 \mathrm{k} \Omega \mathrm{cm}^{2}$, whereas the $R_{\mathrm{ct}}$ values of $\mathrm{MnO} / \mathrm{BCe}, \mathrm{MnOCe} 1 / \mathrm{B}$ and $\mathrm{MnOCe} 2 / \mathrm{B}$ exhibited $\sim 8 \mathrm{k} \Omega \mathrm{cm}^{2}$. The experimental results suggest that the cerium conversion coating or addition of cerium to the silane coating imparts active corrosion protective properties to the coatings reducing the corrosion progress during immersion in the $\mathrm{NaCl}$ solution.

\section{Self-healing ability}

The most suitable way to evaluate self-healing ability is via formation of an artificial defect on the surface and then monitoring its electrochemical behaviour using EIS. In the present work, the $\mathrm{MnO} / \mathrm{BCe}$ sample with defect formation was immersed for $5 \mathrm{~h}$ in a $0.5 \mathrm{M} \mathrm{NaCl}$ solution. The impedance results were fitted using the equivalent circuit presented in Fig. $5 \mathrm{~b}$. The evolution of the resistances $R_{\text {coat }}, R_{\text {mix }}$ and $R_{\mathrm{ct}}$ for the $\mathrm{MnO} / \mathrm{BCe}$ sample after different periods of immersion is presented in Fig. 8. The EIS

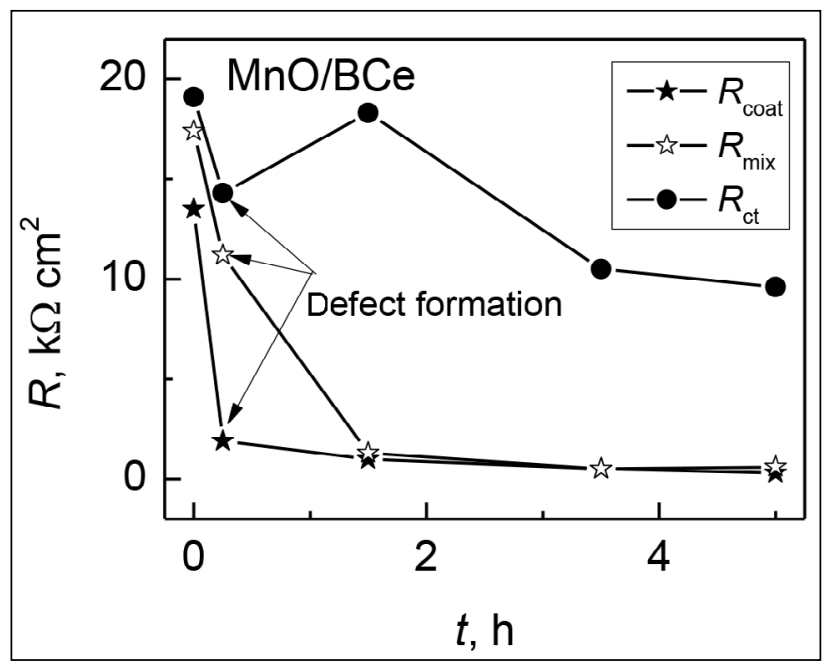

Fig. 8. Evolution of $R_{\text {coat' }} R_{\text {mix }} R_{\text {ct }}$ of $\mathrm{MnO} / \mathrm{BCe}$ before and after defect formation during immersion in $0.5 \mathrm{M} \mathrm{NaCl}$ solution results have shown that one hour after defect formation the values of $R_{\text {coat }}$ and $R_{\text {mix }}$ decreased continuously, whereas the low frequency resistance $R_{\mathrm{ct}}$ increased up to the initial value (Fig. 8). This suggests that the presence of cerium in the silane coating on the $\mathrm{MnO}$ sample can lead to high values of low frequency impedance due to the healing of the defects. It can be clearly seen that after $5 \mathrm{~h}$ of exposure the value of $R_{\mathrm{ct}}$ remains about $10 \mathrm{k} \Omega \mathrm{cm}^{2}$. The experimental results suggest that the addition of cerium to BTESPT imparts active corrosion protective properties reducing the corrosion progress of $\mathrm{MnO} / \mathrm{BCe}$ during immersion in the $\mathrm{NaCl}$ solution.

\section{CONCLUSIONS}

The investigated coatings systems on carbon steel consisted of a phosphate-permanganate layer without/with cerium conversion coatings and an additional outer layer of bis-[triethoxysilylpropyl] tetrasulfide silane (BTESPT), or BTESPT doped with cerium. The SEM studies of the microstructure and cross-section have revealed that the formed silane coatings are free of visible defects and cracks. The value of the average thickness of the silane film was from $\sim 100 \mathrm{~nm}$ to $\sim 390 \mathrm{~nm}$. According to the XPS measurements the calculated amount of Ce in the top layer of the coating $(0-20 \mathrm{~nm})$ varied from 0.27 at. $\%$ to 0.35 at. $\%$.

The results of potentiodynamic polarization measurements have revealed that the silane layer improved the protection efficiency of all the investigated samples. The results of EIS measurements performed during $24 \mathrm{~h}$ immersion of the investigated samples into a $0.5 \mathrm{M} \mathrm{NaCl}$ solution revealed that the layer of silane doped with Ce was more protective than that of the non-modified one.

EIS measurements were applied to study the self-healing ability via formation of an artificial defect on the surface of $\mathrm{MnO} / \mathrm{BCe}$. It has been determined that one hour after defect formation the low frequency impedance increased up to the initial value and after $5 \mathrm{~h}$ of exposure the value of $R_{\mathrm{ct}}$ remained $\sim 10 \mathrm{k} \Omega \mathrm{cm}^{2}$. This suggests that the presence of $\mathrm{Ce}$ in the silane coating can lead to high values of low frequency impedance due to the healing of the defect.

Received 16 April 2019 Accepted 2 May 2019 


\section{References}

1. J. Zhao, G. Frankel, R. L. McCreery, J. Electrochem. Soc., 145, 2258 (1998).

2. S. M. Cohen, Corrosion, 51/1, 71 (1995).

3. H. Umehara, M. Takaya, S. Terauchi, Surf. Coat. Technol., 169-170, 666 (2003).

4. I. Danilidis, J. Hunter, G. M. Scamans, J. M. Sykes, Corros. Sci., 49, 1559 (2007).

5. Y. L. Lee, Y. R. Chu, W. C. Li, C. S. Lin, Corros. Sci., 70, 74 (2013).

6. K. Z. Chong, T. S. Shih, Mater. Chem. Phys., 80, 191 (2003).

7. H. Zhang, G. Yao, S. Wang, Y. Liu, H. Luo, Surf. Coat. Technol., 202, 1825 (2008).

8. S. Pommiers, J. Frayret, A. Castetbon, M. PotinGautier, Corros. Sci., 84, 135 (2014).

9. A. J. Aldykewicz, H. S. Isaacs, A. J. Davenport, J. Electrochem. Soc., 142, 3342 (1995).

10. C. Wang, F. Jiang, F. Wang, Corros. Sci., 46, 75 (2004).

11. M. Fedel, A. Ahniyaz, L. G. Ecco, F. Deflorian, Electrochim. Acta, 131, 71 (2014).

12. M. A. Arenas, J. J. de Damborenea, Surf. Coat. Technol., 187, 320 (2004).

13. Y. Kobayashi, Y. Fujiwara, Electrochim. Acta, 51, 4236 (2006).

14. G. Bikulčius, A. Ručinskienè, A. Sudavičius, V. Burokas, A. Grigucevičienè, Surf. Coat. Technol., 203, 115 (2008).

15. X. Yu, G. Li, J. Alloys Compd., 364, 193 (2004).

16. S. Joshi, E. A. Kulp, W. G. Fahrenholtz, M. J. ƠKeefe, Corros. Sci., 60, 290 (2012).

17. M. F. Montemor, A. M. Simões, M. J. Carmezim, Appl. Surf. Sci., 253, 6922 (2007).

18. M. F. Montemor, A. M. Simões, M. G. S. Ferreira, M. J. Carmezim, Appl. Surf. Sci., 254, 1806 (2008).

19. B. R. W. Hinton, L. Wilson, Corros. Sci., 29, 967 (1989).

20. R. G. Buchheit, S. B. Mamidipally, P. Schmutz, H. Guan, Corros., 58, 3 (2002).

21. M. F. Montemor, M. G. S. Ferreira, R. G. Duarte, A. M. P. Simões, Electrochim. Acta, 49, 2927 (2004).

22. A. Cabral, R. G. Duarte, M. F. Montemor, M. L. Zheludkevich, M. G. S. Ferreira, Corros. Sci., 47, 869 (2005).

23. M. F. Montemor, R. Pinto, M. G. S. Ferreira, Electrochim. Acta, 54, 5179 (2009).

24. D. Wang, G. P. Bierwagen, Prog. Org. Coat., 39, 67 (2009).
25. M. L. Zheludkevich, I. M. Salvado, M. G. S. Ferreira, J. Mater. Chem., 15, 5099 (2005).

26. K. A. Yasakau, M. L. Zheludkevich, O. V. Karavai, M. G. S. Ferreira, Prog. Org. Coat., 63, 352 (2008).

27. W. Trabelsi, E. Triki, L. Dhouibi, M. G. S. Ferreira, M. L. Zheludkevich, M. F. Montemor, Surf. Coat. Technol., 200, 4240 (2006).

28. B. A. Boukamp, J. Electrochem. Soc., 142, 1885 (1995).

29. O. Girčienè, L. Gudavičiūtè, A. Selskis, V. Jasulaitienè, A. Martušienè, R. Ramanauskas, Chemija, 27/1, 1 (2016).

30. D. Weng, P. Jokiel, A. Uebleis, H. Boehni, Surf. Coat. Technol., 88, 147 (1996).

31. M. L. Zheludkevich, R. Serra, M. F. Montemor, K. Y. Yasakau, I. M. Miranda Salvado, M. G. S. Ferreira, Electrochim. Acta, 51, 208 (2005).

32. K. A. Yasakau, J. Carneiro, M. L. Zheludkevich, M. G. S. Ferreira, Surf. Coat. Technol., 246, 6 (2014).

33. K. Jütnerr, Electrochim. Acta 35, 1501 (1990).

\section{O. Girčienè, L. Gudavičiūtė, A. Martušienė,}

V. Jasulaitienè, A. Selskiené, R. Ramanauskas

\section{ANGLINIO PLIENO, PADENGTO CERIU MODIFIKUOTA FOSFATINE- \\ PERMANGANATINE DANGA IR SLUOKSNIU SILANO, PRATURTINTO CERIU, KOROZINĖS APSAUGOS TYRIMAS}

Santrauka

Tirta silano ir silano, praturtinto cerio nitratu, dangu itaka koroziniam atsparumui angliniam plienui, padengtam fosfatine-permanganatine danga $(\mathrm{MnO})$. Pagrindinis darbo tikslas - palyginti cerio konversinių dangų ir cerio, esančio silane, aktyvios korozinès apsaugos, t. y. savaiminio defektuotų vietų užgijimo, galimybes. Pasirinktų pavyzdžių sudètis bei struktūra buvo tirti XPS ir SEM metodais, korozinè elgsena nustatyta elektrocheminiais tyrimais (voltamperometrija ir EIS). EIS tyrimai parodè, kad silano dangoje esantis cerio nitratas, kuris yra korozijos inhibitorius, taip pat kaip ir cerio konversinès dangos, pagerina anglinio plieno apsaugą nuo korozijos. Nustatyta, kad praejus 1 val. po dangos ịbrèžimo, žemų dažnių impedansas padideja iki pradinès vertės, t. y. savaime išnyksta pažeista vieta. 